\title{
Past and Present Fears Among Hazara Refugees in Germany
}

\author{
Erschienen in: ANGST + | FEAR + \\ Von: Sayed Mahdi Mosawi, Volker M. Heins
}

\section{A well-founded fear}

We all know, to some degree at least, the feeling of fear or anxiety, but few can claim that fear fully determines their condition and legal status. This is true only for refugees who are defined by the Geneva Refugee Convention by their "well-founded fear of being persecuted". Well-foundedness of fear contains both a subjective element (fear of persecution and violence) and an objective element (the fear must have an objectively justifiable basis). Refugees are fearful subjects whose fear not only motivates but also entitles them to cross international borders even without travel documents if there is no other way to reach a safe haven. In an ideal world of perfectly functioning international law, no one is illegal as long as the persons seeking protection "present themselves without delay to the authorities" and "show good cause for their illegal entry or presence". 1

The international order envisioned by the drafters of the 1951 Refugee Convention is based on the assumption that fearful subjects fleeing their homelands are able to convince and strike a sympathetic chord with lawyers and ordinary people in places where fear doesn't dominate life.

Unfortunately, and as a general rule, we no longer live in such a world. It is increasingly difficult for victims of violence in the global South to enter Europe or North America. Visible and invisible walls are being erected everywhere to keep out potential migrants and asylum seekers. As a result, their chances to "present themselves" to us are dwindling. This is why Europeans experienced the arrival of unprecedented numbers of refugees in 2015 as a fundamental disruption of the order of things, or as a "crisis". The exiled Syrian writer Yassin al-Haj Saleh, who now lives in Berlin, has made the point that the refugees and migrants from Afghanistan, the Middle East or Africa who have sought shelter in Europe "have invented something new in international politics: crossing multiple borders, that is, erasing borders in an unprecedented way that can be imitated by others". 2

How have migrants experienced this crossing of borders and the subsequent arrival in new places? German sociologist Heinrich Popitz has argued that fear, like hope, is not a natural or automatic reaction to events but rather a malleable emotion always shaped by 
power relations. He speaks of the "social plasticity" of our fears and hopes. ${ }^{3}$ We can be taught to fear by institutions or people who increase their power by threatening us with pain and humiliation. And we can unlearn to be fearful.

With this insight in mind, we asked how refugees were emotionally responding to their new situation after arrival in Germany. Were they able to rebalance what Popitz called their "budgets of fear and hope"? ${ }^{4}$ Or were old fears simply replaced by new ones, leaving little room for hope?

\section{"An extreme sense of fear"}

To answer these questions, we interviewed two young Afghan men from a Shi'a religious background. Both belong to the Hazara ethnic group, a persecuted minority in Afghanistan with a significant diaspora in Pakistan, Iran and Europe. The interviews were conducted in Dari through WhatsApp calls and then translated into English. The two men came to Germany as refugees in 2015, and although they have residence permits, they did not want us to reveal their real names. They preferred to be called Kareem and Zakani.

Like other migrants and refugees, Kareem and Zakani have overcome frightening circumstances to build new lives elsewhere. Kareem, who is now 21 years old, started his journey in Iran, where he was born as the son of an Afghan refugee family, which means that he was not entitled by birth to get an Iranian passport or permanent residency. Instead, he had to extend his residency every year. This, he told us, was a harrowing experience and a source of constant fear: "I lived there with an extreme sense of fear [tars /ترس]".

But there was something even worse to be afraid of. The Iranian government relied heavily on Afghan immigrants for its armed forces, sending them in great numbers to fight in Syria. In exchange for the promise of basic rights like legal residence in Iran, some Hazaras enlisted in the Fatemiyoun Division, an all-Afghan Shi'a militia named after the Prophet Muhammad's youngest daughter. Kareem was not willing to become a soldier, however. Like countless others, he decided to leave the country as well as high school, embarking on a long and risky journey via Turkey to Europe: "Oh boy, it was terrifying! [vahšatnāk / 5 .".

Zakani, a 34-year-old man who had worked in Iran as a studio operator, offers a different story. Unlike Kareem, he was not primarily driven by fear but by the desire to find and join his mother and sister in Turkey. Together they were then caught up in the stream of migrants and moved to Germany as if carried away by the flow towards Europe. On the way, Zakani felt like he was "in a trance [xalsa / خلسه] and a state of confusion [وiji / كيجى". Seeing the moving crowds of refugees, he was asking himself "where all these people were going". Together with his mother and sister, he ended up in a reception camp in Heidelberg, rather clueless about what was going to happen next. Given his state of confusion and uncertainty, he was unable to produce a convincing narrative based on a 
personal story of "well-founded fear", and as a result, his asylum application was rejected. Luckily, he found a decent job that earned him a temporary residence permit and the suspension of his deportation.

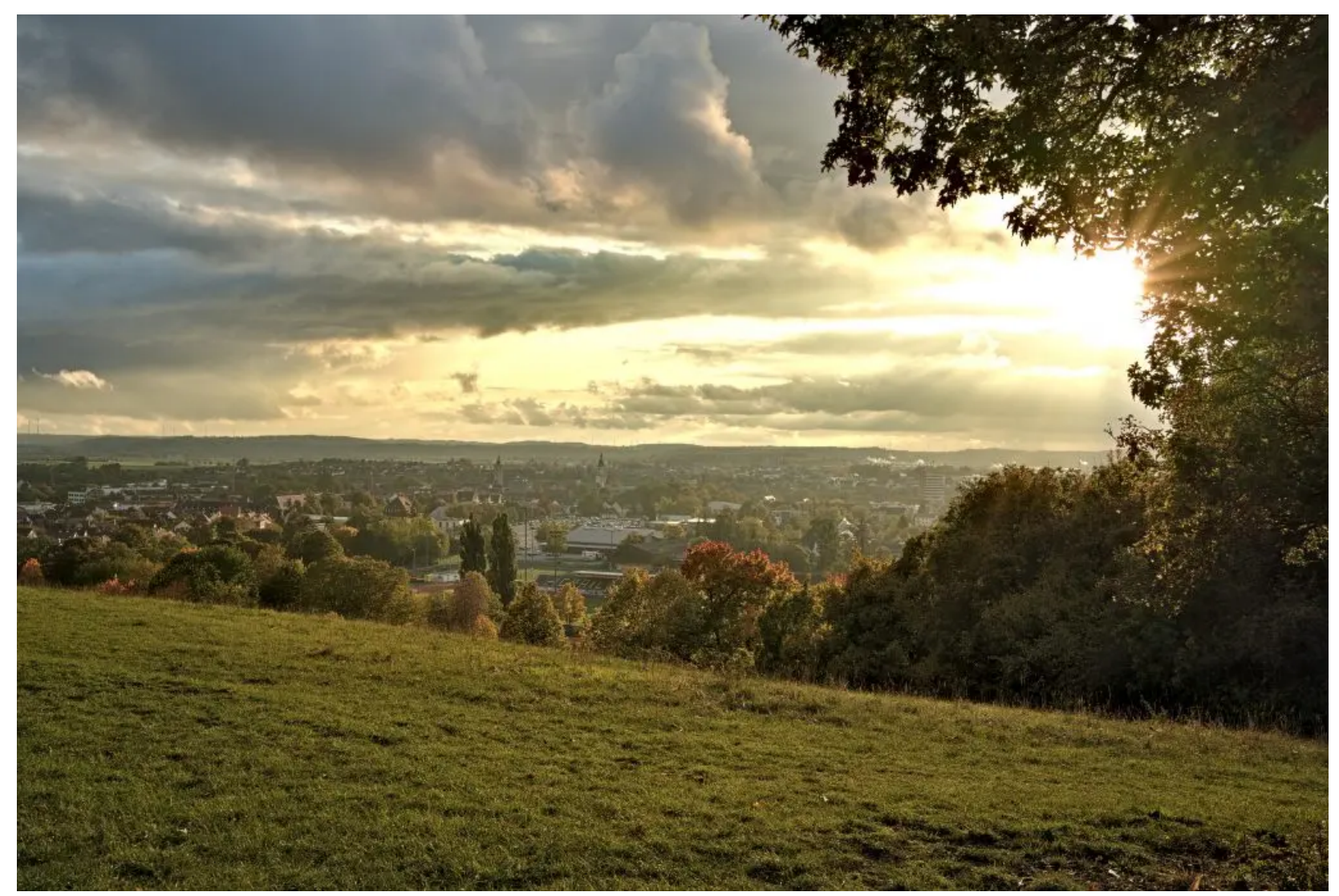

Zakani's new hometown, somewhere between Stuttgart and Nuremberg. ( personal photo taken 2020.

Nevertheless, it is clear that the German state has condemned him to a life in limbo, "freezing" his expectations, as Popitz writes, at a very low level. The rejection of Zakani's asylum application led to a situation in which his "budget" of fears and hopes was "thrown out of balance by extraordinary anxieties". 6 The past might have been dreadful, but the uncertain future gives rise to new fears. Little wonder that Zakani continues to describe his current state of mind as "confused" [āšofte / آنشفته]. His precarious position does not allow him to join the chorus of many other recently arrived refugees who proudly affirm "We are here now"[Wir sind jetzt hier]. ${ }^{7}$

\section{"Fear of injustice"}

If their situation changes, individuals are able, as Popitz has pointed out, "to reset their total budget of fears and hopes", ${ }^{8}$ sometimes almost overnight. Upon arrival in Europe, Kareem promised himself that now, having "come to a country like Germany, why shouldn't I make a great life for myself". He learned the language "with enthusiasm" [eštiyāq / انتشياق] and skillfully navigated the intricacies of the asylum system. Then, with rising expectations, new fears kicked in, some of them even bigger than in Iran, where he didn't believe in having a future anyway. Most of these new fears are rather mundane, like the fear of failing in his apprenticeship or the fear of not being allowed to go to university one day. 
But then there is racism. Kareem told us how scared he was when he once wanted to visit a friend in Leipzig. He was told by his peers to watch out as "Leipzig is full of racists". A German friend who was accompanying Kareem stirred the fear in him that perhaps she would be the one in danger because of her red hair and the prejudices people might hold against redheads. In the end, the trip turned out to be lovely and reassuring. Kareem found out that both redheads and refugees are safe in Leipzig.

Still, racism is very much on the minds of our interviewees. Kareem is closely watching the development of the political situation in Germany and Europe. He is worried that some parties and groups "only appreciate the German race and that's it". Zakani mentions his "fear of injustice" [biEdālati / بـ عدالتى] in everyday life, small gestures of disrespect like the hurtful "sarcastic remarks" he once overheard from a coworker. Zakani gets angry: "He allows himself to talk behind me about my work in a bad way. What does he know about me? That I am an Ausländer from Afghanistan, so I am not capable of doing my job?" One day, he adds, I will "shout at a person who picks on me".

\section{Silver linings}

Popitz writes "that the experience of being compelled to adapt and of being able to adapt is as ancient as the story of the human being. It traveled alongside every stream of refugees". ${ }^{9}$ The randomly chosen cases of Zakani and Kareem demonstrate this insight. Hopes and fears continue to be shaped by changing power relations, but refugees can also distance themselves from old and new fears through self-transformation and what Popitz calls the "'human openness to the world,' our capacity of arranging ourselves for more than one world". 10

Sometimes this capacity is undermined by the new host society and its state. Zakani says that for him, moving to Europe meant that the "taste and form of fear" changed dramatically without going away. Asked where he sees himself in ten years, he replies without hesitation that he has simply no idea. But he says it laughingly and without despair.

This refusal to think about the future may be a way of coping with a situation in which deportation is only a phone call away. Once this fear is taken away from them, refugees have a chance to let go of old and new fears alike. Some may even teach the sedentary citizens of their new home countries a lesson. Kareem answers our question about his hopes for the future in a slightly macho but not unappealing way: "Ten years from now, I see I have a good life. Perhaps it won't be extraordinary but it will be a very good one. You know I am not a sissy (susul / سوسول) like my German fellows. They say that they want to remain in the city where we live because they grew up here and cannot stay far away from it. So, they are dependent on their city. But I am not a dependent [vābaste I [و ابسته person like my German fellows. I am ready to take on all the difficulties on my way".

\section{References}


1. UNHCR (1951/1967): Convention and Protocol Relating to the Status of Refugees, Art. 1(1) and Art. 31(1). https://www.unhcr.org/4d934f5f9.pdf

2. Al-Haj Saleh, Yassin (2018): "Living in the temporary", Yassinhs.com, 17 April. http://www.yassinhs.com/2018/04/17/living-in-the-temporaryl

3. Popitz, Heinrich (2017): Phenomena of Power: Authority, Domination, and Violence. Translated by Gianfranco Poggi, New York: Columbia University Press, p. 67. https://doi.org/10.7312/popi17594

4. Ibid., p. 68.

5. For details and dangers of this route, see Mixed Migration Centre (2020): Destination Unknown: Afghans on the move in Turkey, MMC Middle East Research Report, pp. 32-40. https://mixedmigration.org/resource/destinationunknown-afghans-on-the-move-in-turkey $\underline{1}$

6. Popitz, Phenomena of Power, pp. 69, 68.

7. See the title of the documentary by German filmmaker Niklas Schenck: "Wir sind jetzt hier." Filmgespräch mit Niklas Schenck, Azim Fakhri, Bärbel Kofler et al. https://www.youtube.com/watch?v=9EiOGu4doHQ

8. Popitz, Phenomena of Power, p. 68.

9. Ibid.

10. Ibid., p. 69.

SUGGESTED CITATION: Heins, Volker; Mosawi, Sayed Mahdi: Past and Present Fears Among Hazara Refugees in Germany, in: KWI-Blog,, [https://blog.kulturwissenschaften.de/past-and-present-fears-among-hazara-refugeesin-germany/], 14.06.2021

DOI: https://doi.org/10.37189/kwi-blog/20210614-0830 
Dieser Text wird via DuEPublico, dem Dokumenten- und Publikationsserver der Universität Duisburg-Essen, zur Verfügung gestellt. Die hier veröffentlichte Version der E-Publikation kann von einer eventuell ebenfalls veröffentlichten Verlagsversion abweichen.

DOI: $\quad$ 10.37189/kwi-blog/20210614-0830

URN: urn:nbn:de:hbz:464-20210614-111211-0 